\title{
Entrepreneurship, export orientation, and economic growth
}

\author{
Jolanda Hessels • André van Stel
}

Accepted: 10 September 2009/Published online: 23 October 2009

(C) The Author(s) 2009. This article is published with open access at Springerlink.com

\begin{abstract}
In this paper the relationship between a country's prevalence of new ventures and its rate of economic growth is investigated, while taking into account new ventures' export orientation. It is generally acknowledged that new venture creation as well as export activity may both be important strategies for achieving national economic growth. However, to our knowledge no attempt has been made to investigate empirically the role of export-driven new ventures in economic growth. We focus on the national level and use data for a sample of 34 countries over the period 2002-2008. Our results suggest that, on top of a positive relation between entrepreneurial activity in general and subsequent macroeconomic growth, there is an additional positive effect of export-oriented earlystage entrepreneurship in higher-income countries. However, there is no such additional effect in lowerincome countries.
\end{abstract}

J. Hessels $(\bowtie) \cdot$ A. van Stel

EIM Business and Policy Research, P.O. Box 7001,

2701 AA Zoetermeer, The Netherlands

e-mail: joh@eim.nl

A. van Stel

e-mail: ast@eim.nl

J. Hessels

Erasmus University Rotterdam, Rotterdam,

The Netherlands

A. van Stel

University of Amsterdam, Amsterdam, The Netherlands
Keywords Entrepreneurship - Export ·

International new ventures $\cdot$ Economic growth

JEL Classifications $\quad \mathrm{F} 23 \cdot \mathrm{L} 25 \cdot \mathrm{L} 26 \cdot \mathrm{O} 47 \cdot \mathrm{O} 57$

\section{Introduction}

This paper investigates the relationship between a country's prevalence of new venture creation activity and its rate of economic growth, taking into account new ventures' export orientation. We aim to contribute to three streams of literature: (1) the literature on export and economic growth, (2) the literature on entrepreneurship, in terms of new venture creation, and economic growth, and (3) the literature on new venture internationalization and growth.

First, we aim to contribute to the literature on export and economic growth by examining the role of exportoriented new ventures in economic growth. Export revenues play an important role in achieving economic growth in both low- and high-income countries. Exports are crucial for the economic development of nations (Almeida Couto et al. 2006; Girma et al. 2004; Lages and Montgomery 2004). Exports have a positive impact on the national amount of foreign exchange reserves and on national prosperity, and contribute to the development of national industries, to improved productivity, and to the creation of employment. It is a stylized fact that, on average, exporting firms perform better than nonexporting firms; in particular they tend 
to be more productive, more capital intensive, more innovative, and more efficient (Clerides et al. 1998; Girma et al. 2004; Kneller and Pisu 2007). However, previous research with respect to the importance of export for national economies has strongly focused on established corporations and large multinational enterprises and has paid less attention to the role of start-ups in international markets (Audretsch and Thurik 2000). In this study we attempt to address this gap by examining the relationship between a country's prevalence of export-oriented new ventures and national economic growth.

Second, it is our aim to contribute to the literature on new venture creation and economic growth by explicitly considering new ventures' export orientation. Entrepreneurship, which involves the creation or start-up of new ventures (Gartner 1985), is considered to be an important mechanism of economic development (Baumol 2002; Carree and Thurik 2003; Schumpeter 1934; Wennekers and Thurik 1999) and for developing competitive economies (Hawkins 1993). Audretsch and Keilbach (2004) argue based on empirical studies as well as theoretical arguments that entrepreneurship contributes to economic growth through knowledge spillovers, increased competition, and increased diversity. In particular, entrepreneurs contribute to a process of variety and selection whereby many individual entrepreneurs pursue an observed market opportunity and try to economically exploit a new idea. However, due to increased uncertainty in the global knowledge economy, it is not clear a priori which of these different new ideas are economically viable (Audretsch and Thurik 2000). Only after setting up a new business do entrepreneurs find out what consumers prefer and hence whether their new ideas are economically viable. Most of these new ideas will not be economically viable, but some of them will be. The successful ideas often turn into innovations. When there are more entrepreneurs pursuing new ideas, the level of competition is higher and the process of variety (i.e., a large number of different new ideas being pursued) and selection will be more intense. From an economy-wide point of view this higher intensity increases the probability of actual innovations taking place (i.e., of economically viable ideas being "selected" through the market). Thus, entrepreneurs are important for introducing or generating innovations (Autio 1994; Acs and Audretsch 2003). Several empirical studies confirm a positive relationship between entrepreneurship in terms of new venture creation and national economic growth for developed countries (see, e.g., van Stel 2006). We expect that in investigating the relationship between new venture creation and economic growth it is relevant to take into account new ventures' export orientation. In particular the present paper builds on the assumption that exporting new ventures develop specific skills (including human capital and innovative skills) through their export activity, and consequently a high number of exporting new ventures may be even more conducive to the process of variety and selection described above, compared with high numbers of domestically operating new ventures. In other words, high numbers of exporting new ventures may be of specific importance for generating knowledge spillovers and may have a particularly strong impact on competition and innovation, and subsequently on economic growth.

Third, we aim to extend the literature on new venture internationalization and growth by focusing on the country level. Within the field of entrepreneurship there is increased attention on international new ventures, including export-oriented new ventures (Knight and Cavusgil 1996; McDougall 1989; Oviatt and McDougall 1994). Research on international new ventures was spurred by the finding that international new ventures differ significantly from domestic new ventures in terms of their strategy profile and industry structure (McDougall 1989). Furthermore, interest in international new ventures has also increased because it has been observed that the number of international new ventures is increasing in many different countries around the world (Moen and Servais 2002; Oviatt and McDougall 1994; Rennie 1993) and such ventures are thought to be of importance in terms of innovation and employment (Moen 2002). However, only a few empirical studies have investigated the effect of exports on new ventures' business performance (Bloodgood et al. 1996; McDougall and Oviatt 1996; Zahra et al. 2000), and those that did investigated the link at the micro level. Whereas it is widely believed that internationally oriented new ventures are important in terms of national economic growth (Moen 2002), to our knowledge, this link has not been investigated empirically. This may partly be due to the lack of data (in particular international comparative statistics) concerning the export activity of new firms at the country level. In order to contribute to this gap in 
research, the focus in this study will be on investigating the link between a country's prevalence of new ventures that are oriented toward exports and its rate of economic growth. The advantage of using the country or macro level is that it is possible to capture indirect effects of export-oriented new ventures that reach further than the firms' own performance (economy-wide effects in terms of spillover effects, higher levels of competition, and increased diversity).

Our empirical analysis uses data for 34 countries that have participated in the Global Entrepreneurship Monitor between 2002 and 2005. ${ }^{1}$ We make a distinction between two groups of countries: higherincome countries and lower-income countries. Our model is derived from a model that has been developed by van Stel et al. (2005) for linking new venture creation to economic growth. In the current paper we extend this model by considering the (additional) impact on growth of new ventures' export orientation. The Global Entrepreneurship Monitor data set provides a first attempt to collect international comparative data on the export orientation of a country's early-stage ventures.

The paper is structured as follows. A review of the literature and the development of our hypotheses are presented in Sect. 2. Next, in Sect. 3, we will describe the data and the research method used for the empirical analysis. In Sect. 4 we present the results of our empirical analysis of the association of the presence of new ventures (domestic new ventures and export-oriented new ventures) and national economic growth. Finally, in Sect. 5 we discuss the outcomes and draw some conclusions.

\section{Theory and hypotheses}

2.1 New venture internationalization, firm performance, and learning

The financial merits of export at the firm level are well reported in literature. For example, it is widely

\footnotetext{
1 The countries are Argentina, Australia, Belgium, Brazil, Canada, Chile, China, Denmark, Finland, France, Germany, Greece, Hong Kong, Hungary, Iceland, India, Ireland, Israel, Italy, Japan, Korea, Mexico, The Netherlands, New Zealand, Norway, Poland, Slovenia, South Africa, Spain, Sweden, Switzerland, Thailand, the United Kingdom, and the USA.
}

acknowledged that exports are important for expanding sales, achieving business growth, and improving financial performance (Daniels and Bracker 1989; Edmunds and Khoury 1986; Zahra et al. 1997). It is believed that new ventures may benefit from exporting in terms of improving a venture's competitive performance, financial performance, and growth (Oviatt and McDougall 1997; Zahra et al. 1997). The new venture internationalization model suggests that internationalization is necessary for ensuring opportunities for firm growth (Oviatt and McDougall 1994). However, empirical research on international activities of new ventures has focused mainly on antecedents of earlystage international activity in trying to explain the emergence of internationally oriented new firms or the early internationalization of firms (Zahra 2005). Only a few empirical studies have focused on identifying economic contributions of early-stage firms in terms of growth and profitability (Bloodgood et al. 1996; McDougall and Oviatt 1996; Zahra et al. 2000). These studies find only weak evidence for a positive link between internationalization and performance; for example, Bloodgood et al. (1996), who focused on 61 high-potential new ventures in the USA, found that internationalization was significantly, but only marginally, related to earnings after 2 years, and was not related to sales growth. McDougall and Oviatt (1996) found, for their sample of 62 US new venture manufacturers in the computer and communications equipment industries, that higher levels of export sales were related to higher relative market share 2 years later, but they did not find evidence of a direct significant relation between percentage of foreign sales and subsequent return on investment. Because of this weak empirical foundation more research is needed on the direct as well as indirect effects of new ventures' international operations on economic performance (Zahra et al. 2000).

Export activity may not only generate financial benefits for the firm, but can also be viewed as a process of learning and of accumulation of knowledge and technology (Blalock and Gertler 2004; Yeoh 2004). The economics literature suggests a "learning-by-exporting" effect (Blalock and Gertler 2004; Branstetter 2006; Chuang 1998), and Oviatt and McDougall (1994) argue that international new ventures are also likely to enjoy advantages of knowledge generation through internationalization. In particular, it is suggested that internationalization 
is a source of competitive advantage through which new ventures are able to access resources and thus expand their resource base (Autio 2005; Kuemmerle 1999, 2002; Oviatt and McDougall 1994). Case study evidence suggests that, for ventures that internationalize in early stages, cross-border activities that augment the venture's knowledge base are even more prevalent than cross-border activities that exploit the venture's knowledge base (Kuemmerle 2002). The augmentation of knowledge may relate to different kinds of knowledge; for example, exports may contribute to a firm's innovativeness and technological learning (Branstetter 2006; Hessels 2007; Zahra et al. 2000). Also, exports are likely to result in increased knowledge and higher human capital levels (Lu and Beamish 2001), including the accumulation of knowledge of foreign markets and the development of new organizational capabilities through the accumulation of experience abroad (Johanson and Vahlne 1977; Zahra et al. 2000). Besides, the experience that firms gain from export activity may lead them to explore new foreign markets and become involved in other forms of internationalization, such as licensing, joint ventures or direct investment abroad (Lages and Montgomery 2004).

The view that exporting provides a basis for organizational learning is in line with organizational learning theory (Cohen and Levinthal 1990). In particular, this theory stresses that learning, in the sense of the acquisition, assimilation, and exploitation of new knowledge, provides a base upon which further knowledge and innovations can be developed. The resource-based view (Barney 1991; Wernerfelt 1984), which argues that firm resources are key to the firm's acquisition and maintenance of sustainable competitive advantage, predicts that a firm's ability to enter foreign markets is directly related to the tangible and intangible resources that are available to the firm. The resource-based view also includes capabilities that a firm is able to access or develop through interaction in business relationships. In this sense, undertaking international business activities may be a means for firms to complement or gain access to new resources or to build up new competences. Hence, the resource-based view also recognizes that internationalization may provide a means for firms to accumulate resources.

Regarding learning through internationalization, recent literature suggests a learning advantage of newness for new ventures (Autio et al. 2000; Knight and Cavusgil 2004; Sapienza et al. 2006; Yeoh 2004). Autio et al. (2000) find that internationalization at an early age is positively related to a firm's subsequent international growth. The idea is that internationalization results in innovativeness, knowledge, and capabilities that increase the new venture's probability for growth and for success in foreign markets (Autio et al. 2000; Knight and Cavusgil 2004). Yeoh (2004) also suggests that exposure to foreign markets at an early age of the firm fosters different kinds of learning such as technological learning and foreign market learning. Sapienza et al. (2006) argue that new ventures have a high ability to learn through internationalization because they are less likely to suffer from structural inertia and rigidities (resulting from, e.g., existing routines or resource configurations) than more established organizations. In addition, Lu and Beamish (2001) argue that, since internationalization is particularly risky and uncertain for new ventures, this may stimulate processes of learning and adaptation through foreign market entries.

\subsection{Export-driven new venture creation and economic growth}

In neoclassical or exogenous growth models, economic growth is exogenously determined by technological progress. In contrast, the model of endogenous growth or new economic growth theory proposes that economic growth is driven by the accumulation of knowledge and technologies, which are viewed as forces that are internal to the economic system, i.e., endogenous (Romer 1986). According to Romer's model the stock of human capital is important for economic growth and economies with larger stocks of human capital will experience faster economic growth (Romer 1990).

In the endogenous growth model technological advance comes from individual actions or individual agents with endowments of new economic knowledge. However, while in the endogenous growth models the creation of knowledge is endogenous, the diffusion of knowledge (knowledge spillover) is exogenous. Acs et al. (2006) argue that knowledge does not spill over automatically but instead requires a transmission mechanism such as entrepreneurship. Entrepreneurship plays an important role in the 
transmission of knowledge and consequently is a crucial element in the process of economic growth. Acs et al. (2006) suggest that entrepreneurship or the propensity to start new firms should be added to models explaining economic growth as the knowledge of individuals is commercialized by the start-up of new ventures. Audretsch and Keilbach (2004) argue based on previous empirical studies as well as theoretical arguments that there are three means through which entrepreneurship contributes to economic growth. The first is through knowledge spillovers; the second is through increased competition by the increased number of enterprises; the third is through increased diversity since entrepreneurship increases the variety of enterprises and hence the variety of goods and services offered in an economy. There is indeed empirical evidence that the creation of new ventures exerts a positive influence on economic growth in developed countries (van Stel 2006).

We argue that in particular export-driven new ventures may contribute to the generation of positive knowledge spillovers, to increased competition, and to increased diversity in the economy, and consequently to economic growth. In the economics literature it is considered a stylized fact that exporting firms on average perform better than nonexporting firms. In particular they tend to be more productive, more capital intensive, and more innovative (Girma et al. 2004; Kneller and Pisu 2007). There are two explanations. First, in order to be able to export, firms need some kind of competitive advantage such as unique resources or innovative abilities, because they have to adapt their products or services to foreign markets. Exporting firms either already possess these resources and capabilities before entering a foreign market or they have to develop these since the knowledge and capabilities that the firm has developed for the local or national market are often not suitable to operations abroad ( $\mathrm{Lu}$ and Beamish 2001). Second, export activity has many potential benefits for firms, not only in terms of financial gains, but export may also contribute to learning or competence development. By doing business abroad firms are exposed to new processes and technologies which may further contribute to increased productivity and innovativeness. In sum, exporting facilitates both the exploitation of existing knowledge and the acquisition of new knowledge (e.g., market knowledge and technological knowledge).
We expect that these positive effects of export activity equally apply to new ventures and we find support for this in the literature. For example, the literature on international new ventures suggests that new ventures that are able to export from the start tend to be innovative or possess unique resources, in particular intangible knowledge-based resources (e.g., management experience in global markets or technological capabilities; Bloodgood et al. 1996; Oviatt and McDougall 1994). International new ventures also tend to have high initial levels of human resources (Yeoh 2004). In the previous section we already discussed the learning benefits from exporting for new ventures.

\subsection{Developing the hypotheses}

The concepts developed so far lead us to argue that (early) export may have positive effects on a firm's performance and learning as well as on a country's economy as a whole. First, when many new ventures are oriented toward export, the chance that the knowledge gained through this activity spills over to other firms may be considered high. The reason for this is that small and new firms have a lot of business contacts with other firms (for instance, through cooperation or through buyer-supplier relations) which may lead to exchange of knowledge. Via these so-called spillovers, knowledge may accumulate not only at the firm level (i.e., the exporting firm) but also at the aggregate level (i.e., the firm population in general). Second, since international new ventures both build on their unique knowledge or resources and also accumulate new knowledge and resources through their export activity, they are likely to increase competition in the national market. Third, a higher incidence of exporting new ventures may in particular contribute to more diversity in the economy, since export-oriented new ventures tend to be innovative and they may further increase their innovativeness through foreign market exposure.

Furthermore, we expect that the relationship between export orientation among new ventures and economic growth may differ for different groups of countries along their level of economic development. It is relevant to distinguish between higher-income countries and lower-income countries, since higherincome countries are better integrated into the world economy than lower-income countries (UNCTAD 
2006). In higher-income countries, firms tend to export goods that use specialized skilled labor (Bajona 2004). Consequently exporting firms, including exporting new ventures, tend to have high human capital levels and they are likely to have sufficient absorptive capacity to learn through exporting. In lower-income countries, the rate of necessity entrepreneurship is comparatively high and opportunities to export are more limited for new ventures than in higher-income countries, since new ventures tend to have lower human capital levels and to be active in low-value-added activities. Consequently, export-oriented new ventures in lower-income economies are less likely to increase diversity, to stimulate competition, and to generate positive externalities to other economic actors than are export-oriented new ventures in higher-income countries.

In our analysis we focus on the macro or national level, since a macro analysis provides the possibility to capture both the direct effects of exporting on new venture performance and the indirect effects of exporting new ventures that reach further than their own performance. For instance, an increase in the number of exporting new ventures may stimulate incumbent firms to improve their performance as otherwise the incumbents may no longer be able to compete in the market in which they operate (Fritsch and Mueller 2004). Thus, by using a macrolevel analysis it is possible to incorporate economy-wide effects in terms of knowledge spillovers, increased competition, and increased diversity. To our knowledge, no attempt has been made thus far to link the prevalence of export-oriented new ventures to macroeconomic outcomes.

Based on the arguments developed above we formulate the following three hypotheses:

Hypothesis 1 There is a positive relationship between a country's prevalence of new ventures and its rate of economic growth.

Hypothesis 2 The positive relationship between a country's prevalence of new ventures and its rate of economic growth is more pronounced for exportoriented new ventures versus domestic new ventures.

Hypothesis 3 The positive relationship between a country's prevalence of export-oriented new ventures and its rate of economic growth is more pronounced in higher-income than in lower-income countries.

\section{Methodology}

\subsection{Data and sample}

Data on a country's prevalence of new ventures and new ventures' export orientation are taken from the Global Entrepreneurship Monitor (GEM). We use a sample of 34 countries participating in GEM between 2002 and 2005. The GEM is a worldwide research project aimed at describing and analyzing entrepreneurial activity and the institutional conditions to which this is subjected in a large number of countries. Data are collected through adult population surveys that are conducted in participating countries. In all participating countries representative samples of randomly selected adults (at least 2,000 per country) are surveyed each year. The GEM project offers comparable data across countries, since entrepreneurial activity is consistently measured in a harmonized way across a large number of countries (Reynolds et al. 2005).

Within the framework of GEM a total early-stage entrepreneurial activity (TEA) index has been developed in order to measure early-stage or new entrepreneurial activity. The TEA is a combination of nascent entrepreneurs (those currently involved in concrete activities to start up a new business) and owners of young businesses (those currently owning a business that is less than 42 months old).

Literature on international new ventures describes the internationalization of firms as "a rapid process of international expansion from inception, using a range of market entry modes in multiple markets" (Jones and Coviello 2005, p. 284). However, export activity is considered to be the first and most common step in a firm's international expansion (Young 1987; Young et al. 1988), and export activity is the most common mode of foreign operation for new ventures (Zahra et al. 1997). One reason why exporting is an important means for international expansion among newly established firms is that exporting does not require major capital investments (Erramilli and D'Souza 1993; Root 1994) and has lower commercial and financial risk as compared with, for example, foreign direct investment (Jaffe and Pasternak 1994). Whereas a large number of organizations, such as the World Trade Organization (WTO), the Organisation for Economic Co-operation and Development (OECD), the United Nations (UN) Commodity Trade Statistics Database (COMTRADE), and Eurostat, publish 
international comparative export data, there are no official international comparative export statistics relating to exports by small and new firms. In this respect the Global Entrepreneurship Monitor initiative fills an important gap by providing a harmonized measure for export orientation of new/emerging ventures across countries. In this paper we will focus on new ventures with a strong focus on exports. Ventures with a strong or substantial focus on exports are likely to have a greater knowledge base or to have a higher level of firm-specific advantages and product or service quality (enabling them to have a strong focus on exports) than more moderate exporters (Brooks 2006). Furthermore, the efficiency by which new knowledge is learned and accumulated through internationalization may be higher in ventures with a substantial focus on exports, for example, because such ventures are likely to have greater exposure to various kinds of knowledge (Yeoh 2004).

Our empirical analysis builds on a previous article by van Stel et al. (2005) in which it is investigated whether total early-stage entrepreneurial activity (TEA) is related to gross domestic product (GDP) growth for a sample of countries participating in GEM in 2002. The authors find that TEA indeed positively relates to economic growth but that the influence depends on the level of economic development. In particular the contribution to economic growth is found to be stronger for higher-income countries, as compared with lower-income countries. The authors argue that this may be related to higher human capital levels of entrepreneurs in higher-income countries.

In the current paper we will perform a similar regression analysis but, along with the general TEA, we will also use the proportion of export-oriented new ventures (within TEA) as an independent variable. Recent insights not only indicate that new venture internationalization is an important phenomenon to study but also that the age at which new ventures internationalize is important; for example, it has been argued that, the earlier a firm internationalizes, the more likely it is that the firm will develop capabilities for adaptation to uncertain environments (Sapienza et al. 2006). Research has also found that early initiation of internationalization is associated with faster international growth (Autio et al. 2000). Based on these insights we want to include new ventures that focus on exports in their earliest stages and therefore we use the TEA index including both those actively involved in starting a new venture and entrepreneurs of young businesses. Such a definition corresponds with the view that it is essential for international new ventures to view the domain in which they operate “(...) as international from the initial stages of the firm's operation” (McDougall 1989, p. 387).

Besides data on new venture creation activity and new ventures' export orientation from GEM we also use data from secondary sources on GDP growth, per capita income, and the growth competitiveness index (GCI). The sources and definitions of all variables we use are described below.

\subsection{Measures}

\subsubsection{Growth of GDP ( $\triangle G D P)$}

The dependent variable in this study is the 4-year average (i.e., the average over years $t$ to $t-3$ ) of real GDP growth. Real GDP growth rates are taken from the International Monetary Fund (IMF) World Economic Outlook database (April 2008 version).

\subsubsection{Total early-stage entrepreneurial activity}

We use the total early-stage entrepreneurial activity (TEA) as a proxy for a country's prevalence of new ventures. TEA is defined as the percentage of adult population that is either actively involved in starting a new venture or is the owner/manager of a business that is less than 42 months old. Data on total earlystage entrepreneurial activity are taken from the GEM Adult Population Survey. TEA is included in the model with a 3 -year lag. ${ }^{2}$

\subsubsection{Export-oriented new ventures}

We use the proportion of export-oriented new ventures within TEA as a proxy for a country's prevalence of export-oriented entrepreneurial activity. This variable, denoted as "Export-oriented new ventures" (or, in Eq. 1, as "Export"), is defined as the percentage of

\footnotetext{
${ }^{2}$ Several studies show that, besides an indirect or mediumterm impact, new firms also have a direct or immediate impact on macroeconomic performance (e.g., Fritsch and Mueller 2004). Therefore, we choose the year for which we measure TEA to overlap with the first year over which we measure 4-year economic growth.
} 
early-stage entrepreneurs (as defined above) for which the share of customers living abroad is $26 \%$ or more. $^{3}$ These data are also taken from GEM.

\subsubsection{Per capita income (GDPC)}

Gross domestic product per capita is expressed in (thousands of) purchasing power parities per international dollar. These data are taken from the IMF World Economic Outlook database (April 2008 version).

\subsubsection{Growth competitiveness index}

Data on the growth competitiveness index (GCI) are taken from various versions of The Global Competitiveness Report. The GCI is constituted of the following three main factors assessing a country's potential for economic growth: the quality of the macroeconomic environment, the state of the public institutions, and the level of technology. For further details about this index we refer to McArthur and Sachs (2002).

\subsection{Analysis}

We investigate whether a country's level of entrepreneurship (in terms of the prevalence of new ventures) may be considered a determinant of economic growth, next to technology, public institutions, and the macroeconomic environment (which are captured in a combined way by the GCI). As both entrepreneurship and the factors underlying the GCI are assumed to be structural characteristics of an economy, we do not want to explain short-term economic growth but rather growth in the medium term. Therefore, we choose average annual real GDP growth over a period of 4 years as the dependent variable in this study. Following van Stel et al. (2005) we use (the log of) initial income level of countries, to correct for catch-up effects, and lagged growth of GDP, to correct for reversed causality effects, as additional control variables.

We also allow for the possibility of different effects of highly developed and developing countries.

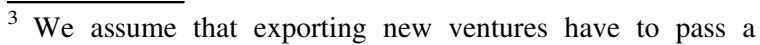
threshold level of export activity in order to actually increase their human capital levels (e.g., by learning from the experience gained abroad) so that they contribute to macro growth (Moen 2002).
}

For this purpose we assign countries to higher- or lower-income categories on the basis of their overall prosperity. ${ }^{4}$ TEA rates may reflect different types of new ventures in countries with different development levels. In particular, human capital levels may differ between higher- and lower-income countries, implying different impacts on economic growth. This is tested by defining separate TEA variables for different groups of countries (higher-income versus lowerincome; also labeled rich versus poor). Our model is represented by Eq. 1, where $i$ and $t$ are indicators for country and time, respectively. Hypothesis 1 corresponds to parameters $b_{1}$ and $c_{1}$ being greater than zero. The hypothesis that the positive relationship between a country's prevalence of new ventures and its rate of economic growth is more pronounced for export-oriented new ventures as compared with domestic new ventures (Hypothesis 2) corresponds to $b_{2} \quad\left(c_{2}\right)$ being greater than zero. Hypothesis 3 implies that coefficient $b_{2}$ is larger than coefficient $c_{2}$.

$$
\begin{aligned}
\Delta \mathrm{GDP}_{i(t, t-3)}= & a+b_{1} \mathrm{TEA}_{i, t-3}^{\text {rich }}+c_{1} \mathrm{TEA}_{i, t-3}^{\text {poor }} \\
& +b_{2} \operatorname{Export}_{i, t-3}^{\text {rich }}+c_{2} \operatorname{Export}_{i, t-3}^{\text {poor }} \\
& +d \log \left(\operatorname{GDPC}_{i, t-3}\right)+e \mathrm{GCI}_{i, t-3} \\
& +f \Delta \mathrm{GDP}_{i(t-4, t-7)}+\varepsilon_{i, t} .
\end{aligned}
$$

Table 1 provides descriptive statistics. Compared with higher-income countries, lower-income countrieswhich tend to have a high proportion of entrepreneurial activity out of necessity-have higher levels of entrepreneurship in general (TEA), whereas higherincome countries have a greater proportion of exportoriented new ventures (Acs et al. 2004). We also see that lower-income countries have experienced higher growth rates recently, suggesting that on average they are catching up with higher-income countries.

\section{Results}

We estimate our model using ordinary least squares (OLS). We estimate five model variants. The first model estimates the model using only control variables, i.e., omitting the TEA and export orientation variables. In

\footnotetext{
${ }^{4}$ Specifically, following the classification used by the World Bank, the lower-income category includes "low-income economies," "lower-middle-income economies," and "upper-middle-income economies," while the higher-income category includes "high-income economies."
} 
Table 1 Descriptives

Notes: The descriptive statistics refer to the model variables from Eq. 1, hence $\Delta \mathrm{GDP}$ is an average over years $t$ to $t-3$ while all other variables are 3-year lagged. The descriptives refer to the estimation sample 2005-2008

\begin{tabular}{lcrrrr}
\hline & $\Delta$ GDP & TEA & Export-oriented new ventures & $\log (\mathrm{GDPC})$ & GCI \\
\hline Higher-income countries $(N=55)$ & & & & \\
Mean & 3.2 & 6.6 & 18.3 & 10.2 & 5.2 \\
Standard deviation & 1.5 & 3.2 & 8.2 & 0.2 & 0.4 \\
Minimum & 0.4 & 1.5 & 0.0 & 9.5 & 4.3 \\
Maximum & 7.2 & 14.5 & 43.2 & 10.7 & 6.0 \\
Lower-income countries & $(N=25)$ & & & \\
Mean & 5.9 & 12.2 & 10.0 & 8.9 & 4.0 \\
Standard deviation & 2.5 & 6.1 & 8.6 & 0.5 & 0.4 \\
Minimum & 2.3 & 2.5 & 1.0 & 7.4 & 3.2 \\
Maximum & 10.5 & 27.3 & 32.5 & 9.4 & 4.9 \\
\hline
\end{tabular}

the second model these two variables are included to see how much entrepreneurship contributes to explaining economic growth rates. In the third model we allow the effects of the entrepreneurship variables to be different for low- and high-income countries. Models 4 and 5 report the results of a robustness test where we use the fitted values of an equation explaining the proportion of export-oriented new ventures from various other variables, including foreign direct investment (FDI) volumes, industry structure, inflation, gross domestic product, etc. ${ }^{5}$ We do this because the export-oriented new ventures variable may be endogenous to economic growth. ${ }^{6}$ In particular, we use the fitted values of a country's proportion of export-oriented new ventures, associated with Table 3, Model 8, reported in De Clercq et al. (2008). In Table 2 below this variable is indicated as "FIT export-oriented new ventures."

Our estimation sample is 2005-2008. This corresponds to an unbalanced panel of 80 observations of countries participating in GEM in the years 2002-2005 (note the 3-year lag in Eq. 1). ${ }^{7}$ Our model aims at explaining country variations in economic growth rates, hence we do not include country dummies in our

\footnotetext{
${ }^{5}$ GDP levels are a proxy for the size of the domestic market. De Clercq et al. (2008) find evidence that export orientation of (early-stage) entrepreneurs is negatively influenced by the size of the domestic market.

${ }^{6}$ Note that we avoid reversed causality in two other ways as well. First, all independent variables of our model are included with a lag. Second, we include a lagged dependent variable on the right-hand side.

${ }^{7}$ We realize that pooling the country data over the years would have reduced measurement error in the sometimes low prevalence of export-oriented new firms. However, that would have reduced the number of observations to be used in the regression analysis from 80 to 34 .
}

model. On the other hand we do include year dummies to correct for worldwide cyclical variations in economic growth rates. Table 2 presents the results.

Model 1 provides results excluding the entrepreneurship variables. As expected, per capita income has a strongly negative impact on economic growth, confirming that lower-income (poorer) countries are catching up with higher-income (richer) countries. Contrary to our expectations, the growth competitiveness index does not contribute to economic growth. We find a strong positive effect of lagged growth suggesting a significant degree of path dependency (i.e., countries growing relatively quickly in a certain period also grow quickly in the next period).

In Model 2 the TEA index and the proportion of export-oriented new ventures are included in the model. We see that the (adjusted) $R^{2}$ increases considerably, by some 8 percentage points. This confirms the importance of entrepreneurship for explaining economic growth (van Stel 2006). We see that both TEA and export orientation of entrepreneurs are significantly positively related to economic growth, providing support for Hypotheses 1 and 2, respectively.

In Model 3 separate coefficients are estimated for rich and poor countries. The result of a likelihood ratio test shows that this distinction does not significantly improve the model fit compared with Model 2. Indeed we see that coefficients for TEA are similar for rich and poor countries. ${ }^{8}$ However, coefficients for export

\footnotetext{
8 This is an important difference from Van Stel et al. (2005), who found a significantly higher coefficient for rich countries. A possible explanation is that their model was estimated for a cross-section of 36 countries for one particular year (2002). The current paper uses a pooled estimation sample of four different years. More research is required on this relation.
} 
Table 2 Explaining economic growth from TEA and export orientation $(N=80)$

\begin{tabular}{|c|c|c|c|c|c|}
\hline & Model 1 & Model 2 & Model 3 & Model 4 & Model 5 \\
\hline Constant & $\begin{array}{l}22.0 * * \\
(8.8)\end{array}$ & $\begin{array}{l}17.0 * * \\
(6.2)\end{array}$ & $\begin{array}{l}19.3 * * \\
(4.4)\end{array}$ & $\begin{array}{l}18.2^{* *} \\
(6.6)\end{array}$ & $\begin{array}{l}20.4 * * \\
(4.9)\end{array}$ \\
\hline TEA & & $\begin{array}{l}0.14 * * \\
(4.8)\end{array}$ & & $\begin{array}{l}0.17 * * \\
(5.4)\end{array}$ & \\
\hline TEA rich countries & & & $\begin{array}{l}0.12 * \\
(2.3)\end{array}$ & & $\begin{array}{l}0.15^{* * *} \\
(2.9)\end{array}$ \\
\hline TEA poor countries & & & $\begin{array}{l}0.15^{* *} \\
(3.8)\end{array}$ & & $\begin{array}{l}0.17 * * \\
(4.6)\end{array}$ \\
\hline Export-oriented new ventures & & $\begin{array}{l}0.048 * \\
(2.2)\end{array}$ & & & \\
\hline Export-oriented new ventures, rich countries & & & $\begin{array}{l}0.066^{* * *} \\
(2.7)\end{array}$ & & \\
\hline Export-oriented new ventures, poor countries & & & $\begin{array}{l}0.008 \\
(0.3)\end{array}$ & & \\
\hline FIT export-oriented new ventures & & & & $\begin{array}{l}0.11 * * \\
(4.2)\end{array}$ & \\
\hline FIT export-oriented new ventures, rich countries & & & & & $\begin{array}{l}0.12^{* *} \\
(4.5)\end{array}$ \\
\hline FIT export-oriented new ventures, poor countries & & & & & $\begin{array}{l}0.073 \\
(1.8)\end{array}$ \\
\hline $\log (\mathrm{GDPC})$ & $\begin{array}{c}-1.6^{* *} \\
(4.5)\end{array}$ & $\begin{array}{c}-1.3^{* *} \\
(4.1)\end{array}$ & $\begin{array}{c}-1.5^{* *} \\
(3.4)\end{array}$ & $\begin{array}{c}-1.5^{* *} \\
(4.8)\end{array}$ & $\begin{array}{c}-1.7 * * \\
(3.9)\end{array}$ \\
\hline GCI & $\begin{array}{c}-0.55 \\
(1.3)\end{array}$ & $\begin{array}{c}-0.57 \\
(1.7)\end{array}$ & $\begin{array}{c}-0.56 \\
(1.7)\end{array}$ & $\begin{array}{c}-0.61 * \\
(2.1)\end{array}$ & $\begin{array}{c}-0.66^{*} \\
(2.5)\end{array}$ \\
\hline Lagged GDP growth & $\begin{array}{l}0.31 * * \\
(3.3)\end{array}$ & $\begin{array}{l}0.35^{* *} \\
(4.2)\end{array}$ & $\begin{array}{l}0.33^{* *} \\
(3.3)\end{array}$ & $\begin{array}{l}0.37 * * \\
(5.0)\end{array}$ & $\begin{array}{l}0.34 * * \\
(4.0)\end{array}$ \\
\hline Log likelihood & -141.0 & -132.3 & -130.5 & -123.4 & -122.2 \\
\hline$R^{2}$ & 0.566 & 0.652 & 0.668 & 0.722 & 0.731 \\
\hline Adjusted $R^{2}$ & 0.530 & 0.613 & 0.619 & 0.691 & 0.692 \\
\hline
\end{tabular}

Absolute heteroskedasticity-consistent $t$-values are between brackets

Year dummies included but not reported

* Significant at a 0.05 level

** Significant at a 0.01 level

orientation are different. In particular, while a higher proportion of export-oriented new ventures contributes significantly to achieving higher macroeconomic growth rates in higher developed countries, this is not the case in lower developed countries. This provides support for Hypothesis 3.

Finally, when using the fitted values of the De Clercq et al. (2008) study for exporting new ventures (Models 4 and 5), we see that the results are qualitatively the same as those of Models 2 and 3. The results are more pronounced though, as witnessed by the higher $R^{2}$ value. We note that in Model 5 export orientation of new ventures has a higher coefficient compared with in Model 3. However, the coefficient is not significantly different from zero.

\section{Discussion and conclusion}

This paper investigates the relationship between new venture creation and economic growth, while taking into account new ventures' export orientation. Our 
findings confirm a positive impact of entrepreneurship in general on economic growth and also illustrate that export orientation makes a significant additional contribution to economic growth. This suggests that in particular export-driven new ventures will contribute to the generation of knowledge spillovers, increased competition, and increased diversity, ultimately resulting in higher economic growth rates. These findings further underline the relevance of making a distinction between exportoriented and nonexporting new ventures in international entrepreneurship research and provide additional support for studying cross-border behavior of new ventures (McDougall 1989; McDougall and Oviatt 2000; Oviatt and McDougall 1994, 2004, 2005; Wright and Ricks 1994).

We examine the role of domestic and exportdriven new ventures in GDP growth for two groups of countries: higher-income economies and lowerincome economies. The distinction between both groups of countries relates to the shift from the managed to the entrepreneurial economy (Audretsch and Thurik 2001). In particular, the nature of entrepreneurship is likely to be different in higherand lower-income countries, hence the impact on economic growth may also differ (van Stel et al. 2005). We find that in higher-income countries new ventures with a strong orientation towards exports make a significant additional contribution to economic growth, whereas this is not the case in lowerincome countries. In higher-income countries, technologies are in general more widely available than in less developed countries and enterprises increasingly specialize in knowledge-based activities. Therefore, new ventures' foreign operations may be based on the presence of specific technological knowledge, skills, and valuable resources that are available within the firm (Oviatt and McDougall 1997). For these ventures international expansion is viable and sometimes even necessary for survival. Furthermore, these ventures are likely to develop specific skills (including innovative skills) through their export activity, and may therefore have a particularly strong impact on economic growth.

From a policy perspective our findings suggest that it may be beneficial for governments in higherincome countries to focus on stimulating strong export ambitions among new ventures. As part of such a strategy governments could strive to stimulate new ventures with a moderate export orientation to become high-level exporters. This might be particularly challenging though, since research indicates that low-intensity exporters are likely to remain lowintensity exporters and that high-intensity exporters are likely to remain high-intensity exporters (Brooks 2006; Moen 2002). Also, governments could introduce new ventures' export growth possibilities and ambitions as a selection criterion in export promotion programs.

It is generally considered that integration into the world economy is an important route for developing countries to achieve sustained economic growth (see Fischer 2003 for an overview of the literature on openness to trade and growth among developing countries). However, the results of our study reveal that export-oriented new ventures do not seem to make an additional contribution (as compared with domestic new ventures) to economic growth in lowerincome countries. It has been suggested that inward FDI is the dominant source of entrepreneurial activity in many lower-income countries (Acs and Virgill 2009) and may in particular result in increased opportunities for entrepreneurs in the domestic market (De Clercq et al. 2008), which may explain why domestic-oriented activities are no less important than export-oriented activities in developing countries. Overall, our results underline that a development strategy based on FDI and its associated entrepreneurial activity may be beneficial for achieving economic growth in developing countries (Acs and Virgill 2009; Naudé 2008).

Traditional stage models propose that internationalization of firms follows a process of gradual expansion into foreign markets after firms have first established a domestic presence (Johanson and Vahlne 1977, 1990). These models predict that early internationalization may negatively affect firm survival. Conversely, researchers on new venture internationalization argue that early internationalization is viewed as necessary for ensuring opportunities for firm growth (Oviatt and McDougall 1994; Zahra et al. 2000) and thus emphasize positive outcomes through early-stage internationalization (Sapienza et al. 2006). However, both the stage models and the model for new venture internationalization (Oviatt and McDougall 1994) do not take into account the outcomes of internationalization at both the firm level (Autio 2005) and the macro level, including spillover 
effects. Consequently, a complete theoretical model that explicitly incorporates outcomes of internationalization is still lacking (Autio 2005). We hope that our study will stimulate more researchers to investigate outcomes of new venture internationalization and subsequently that such studies will contribute to the development of a theoretical model of new venture internationalization that includes various outcome effects.

A limitation of this study is the small sample size. Therefore, the results of our study should be interpreted with care. To gain more detailed insight into the various outcomes of new ventures' export orientation at the firm level as well as the macro level, future studies should strive to collect and analyze longitudinal microlevel data and macrolevel panel data. The skill content of export is likely to induce learning and growth (An and Iyigun 2004) and therefore future studies on the relationship between new venture export and economic growth should try to take into account the skill content of new venture's export. Furthermore, we only focus on export orientation and not on other modes of internationalization. Although exports represent the dominant mode of international involvement for new ventures (Zahra et al. 1997), future research could benefit greatly from also including other modes of internationalization.

Acknowledgments We are grateful to an anonymous reviewer for providing useful comments and to Chantal Hartog for providing us with excellent research assistance. The paper has been written in the framework of the research program SCALES carried out by EIM and financed by the Dutch Ministry of Economic Affairs.

Open Access This article is distributed under the terms of the Creative Commons Attribution Noncommercial License which permits any noncommercial use, distribution, and reproduction in any medium, provided the original author(s) and source are credited.

\section{References}

Acs, Z. J., Arenius, P., Hay, M., \& Minniti, M. (2004). Global entrepreneurship monitor 2004 executive report. Wellesley, MA/London: Babson College and London Business School.

Acs, Z. J., \& Audretsch, D. B. (2003). Innovation and technological change. In Z. J. Acs \& D. B. Audretsch (Eds.), Handbook of entrepreneurship research: An interdisciplinary survey and introduction (pp. 55-80). Dordrecht, The Netherlands: Kluwer.
Acs, Z. J., Audretsch, D. B., Braunjerhelm, P., \& Carlsson, B. (2006). The knowledge spillover theory of entrepreneurship. CESIS Electronic Working Paper Series, Paper No. 77.

Acs, Z. J., \& Virgill, N. (2009). Entrepreneurship in developing countries. Jena Economic Research Papers 2009023.

Almeida Couto, J. P., Borges Tiagio, M. T., Vieira, J. C., \& Fortuna, M. A. (2006). Contextual and operational determinants of export performance of companies in Europe. The Business Review, 5(1), 145-154.

An, G., \& Iyigun, M. F. (2004). The export skill content, learning by exporting and economic growth. Economic Letters, 84(1), 29-34.

Audretsch, D. B., \& Keilbach, M. (2004). Entrepreneurship capital and economic performance. Regional Studies, 38(8), 949-959.

Audretsch, D. B., \& Thurik, A. R. (2000). Capitalism and democracy in the 21 st century: From the managed to the entrepreneurial economy. Journal of Evolutionary Economics, 10(1), 17-34.

Audretsch, D. B., \& Thurik, A. R. (2001). What's new about the new economy? From the managed to the entrepreneurial economy. Industrial and Corporate Change, 10(1), 267-315.

Autio, E. (1994). New technology-based firms as agents of R\&D and innovation. Technovation, 14(4), 259-273.

Autio, E. (2005). Creative tension: The significance of Ben Oviatt's and Patricia McDougall's article 'toward a theory of international new ventures'. Journal of International Business Studies, 36(1), 9-19.

Autio, E., Sapienza, H. J., \& Almeida, J. G. (2000). Effects of age at entry, knowledge intensity, and imitability on international growth. Academy of Management Journal, 43(5), 909-924.

Bajona, C. (2004). Specific factors, learning and the dynamics of trade. International Economic Review, 45(2), 499-521.

Barney, J. (1991). Firm resources and sustained competitive advantage. Journal of Management, 17(1), 99-120.

Baumol, W. (2002). The free-market innovation machine: Analyzing the growth miracle of capitalism. Princeton, NJ: Princeton University Press.

Blalock, G., \& Gertler, P. J. (2004). Learning from exporting revisited in a less developed setting. Journal of Development Economics, 75(2), 397-416.

Bloodgood, J. M., Sapienza, H. J., \& Almeida, J. G. (1996). The internationalization of new high-potential U.S. ventures: Antecedents and outcomes. Entrepreneurship Theory and Practice, 20(4), 61-76.

Branstetter, L. (2006). Is foreign direct investment a channel of knowledge spillovers? Evidence from Japan's FDI in the United States. Journal of International Economics, 68, 325-344.

Brooks, E. L. (2006). Why don't firms export more? Product quality and Colombian plants. Journal of Development Economics, 80(1), 160-178.

Carree, M. A., \& Thurik, A. R. (2003). The impact of entrepreneurship on economic growth. In Z. J. Acs \& D. B. Audretsch (Eds.), Handbook of entrepreneurship research (pp. 437-471). Boston, MA: Kluwer.

Chuang, Y. (1998). Learning by doing, the technology gap, and growth. International Economic Review, 39(3), 697-721. 
Clerides, S. K., Lach, S., \& Tybout, J. R. (1998). Is learning by exporting important? Micro-dynamic evidence from Colombia, Mexico, and Morocco. Quarterly Journal of Economics, 113(3), 903-947.

Cohen, W., \& Levinthal, D. (1990). Absorptive capacity: A new perspective on learning and innovation. Administrative Science Quarterly, 35(1), 128-152.

Daniels, J. D., \& Bracker, J. (1989). Profit performance: Do foreign operations make a difference? Management International Review, 29(1), 46-56.

De Clercq, D., Hessels, J., \& van Stel, A. J. (2008). Knowledge spillovers and new ventures' export orientation. Small Business Economics, 31(3), 283-303.

Edmunds, S., \& Khoury, S. (1986). Exports: A necessary ingredient in the growth of small business firms. Journal of Small Business Management, 24(4), 54-65.

Erramilli, M. K., \& D'Souza, D. E. (1993). Venturing into foreign markets: The case of the small service firm. Entrepreneurship Theory and Practice, 17(3), 29-41.

Fischer, S. (2003). Globalization and its challenges. American Economic Review, 93(2), 1-30.

Fritsch, M., \& Mueller, P. (2004). The effects of new business formation on regional development over time. Regional Studies, 38, 961-975.

Gartner, W. B. (1985). A framework for describing and classifying the phenomenon of new venture creation. Academy of Management Review, 10(4), 696-706.

Girma, S., Greenaway, D., \& Kneller, R. (2004). Does exporting increase productivity? A microeconomic analysis of matched firms. Review of International Economics, 12(5), 855-866.

Hawkins, D. I. (1993). New business entrepreneurship in the Japanese economy. Journal of Business Venturing, 8(2), 137-150.

Hessels, S. J. A. (2007). Innovation and international involvement of Dutch SMEs. International Journal of Entrepreneurship and Small Business, 4(3), 234-255.

Jaffe, E. D., \& Pasternak, H. (1994). An attitudinal model to determine the export intention of non-exporting small manufacturers. International Marketing Review, 11(3), 17-32.

Johanson, J., \& Vahlne, J.-E. (1977). The internationalization process of the firm: A model of knowledge development and increasing foreign market commitments. Journal of International Business Studies, 8(1), 23-32.

Johanson, J., \& Vahlne, J.-E. (1990). The mechanism of internationalization. International Marketing Review, 7(4), 11-24.

Jones, M. V., \& Coviello, N. E. (2005). Internationalisation: Conceptualising and entrepreneurial process of behaviour in time. Journal of International Business Studies, 36(3), 284-303.

Kneller, R., \& Pisu, M. (2007). Industrial linkages and export spillovers from FDI. The World Economy, 30(1), 105134.

Knight, G. A., \& Cavusgil, S. T. (1996). The born global firm: A challenge to traditional internationalization theory. In $\mathrm{S}$. T. Cavusgil \& T. K. Madsen (Eds.), Export internationalizing research-enrichment and challenges (Advances in International Marketing Series, Vol. 8) (pp. 11-26). New York: JAI.
Knight, G. A., \& Cavusgil, S. T. (2004). Innovation, organizational capabilities, and the born-global firm. Journal of International Business Studies, 35(2), 124-141.

Kuemmerle, W. (1999). Foreign direct investment in industrial research in the pharmaceutical and electronics industries: Results from a survey of multinational firms. Research Policy, 28(2-3), 179-193.

Kuemmerle, W. (2002). Home base and knowledge management in international new ventures. Journal of Business Venturing, 17(2), 99-122.

Lages, L. F., \& Montgomery, D. B. (2004). Export performance as an antecedent of export commitment and marketing strategy adaptation. Evidence from small and medium-sized exporters. European Journal of Marketing, 38(9-10), 1186-1214.

Lu, J. W., \& Beamish, P. W. (2001). The internationalization and performance of SMEs. Strategic Management Journal, 22(6-7), 565-586.

McArthur, J. W., \& Sachs, J. D. (2002). The growth competitiveness index: Measuring technological advancement and the stages of development. In M. E. Porter, J. D. Sachs, et al. (Eds.), The global competitiveness report 2001-2002. New York: Oxford University Press.

McDougall, P. P. (1989). International versus domestic entrepreneurship: New venture strategic behaviour and industry structure. Journal of Business Venturing, 4(6), 387400.

McDougall, P. P., \& Oviatt, B. M. (1996). New venture internationalization, strategic change, and performance: A follow-up study. Journal of Business Venturing, 11(1), 23-40.

McDougall, P. P., \& Oviatt, B. M. (2000). International entrepreneurship: The intersection of two research paths. Academy of Management Journal, 43(5), 902-906.

Moen, O. (2002). The born globals: A new generation of small European exporters. International Marketing Review, 19(2), 156-175.

Moen, O., \& Servais, P. (2002). Born global or gradual global? Examining the export behavior of small and mediumsized enterprises. Journal of International Marketing, 10(3), 49-72.

Naudé, W. (2008). Entrepreneurship in economic development. Research paper No. 2008/20, United Nations University, UNU-WIDER, World Institute for Development Economics Research.

Oviatt, B. M., \& McDougall, P. P. (1994). Toward a theory of international new ventures. Journal of International Business Studies, 25(1), 45-64.

Oviatt, B. M., \& McDougall, P. P. (1997). Challenges for internationalization process theory: The case of international new ventures. Management International Review, 37(2), 85-99.

Oviatt, B. M., \& McDougall, P. P. (2004). The internationalization of entrepreneurship. Journal of International Business Studies, 25(1), 2-8.

Oviatt, B. M., \& McDougall, P. P. (2005). Defining international entrepreneurship and modeling the speed of internationalization. Entrepreneurship Theory and Practice, 29(5), 537-553.

Rennie, M. W. (1993). Global competitiveness: Born global. The McKinsey Quarterly, 4, 45-52. 
Reynolds, P., Bosma, N., Autio, E., Hunt, S., De Bono, N., Servais, I., et al. (2005). Global entrepreneurship monitor: Data collection design and implementation 1998-2003. Small Business Economics, 24(3), 205-231.

Romer, P. M. (1986). Increasing returns and long-run growth. Journal of Political Economy, 94(5), 1002-1037.

Romer, P. M. (1990). Endogenous technological change. Journal of Political Economy, 98(5, part 2), S71-S102.

Root, F. (1994). Entry strategies for international markets (rev. ed.). Lexington, MA: Lexington Books.

Sapienza, H. J., Autio, E., George, G., \& Zahra, S. A. (2006). A capabilities perspective on the effects of early internationalization on firm survival and growth. Academy of Management Journal, 31(4), 914-933.

Schumpeter, J. A. (1934). The theory of economic development. Cambridge, MA: Harvard University Press.

UNCTAD. (2006). World Investment Report 2006. FDI from developing and transition economies: Implications for development. New York/Geneva: United Nations.

van Stel, A. (2006). Empirical analysis of entrepreneurship and economic growth (International Studies in Entrepreneurship Series, Vol. 13). New York: Springer.

van Stel, A., Carree, M., \& Thurik, A. R. (2005). The effect of entrepreneurial activity on national economic growth. Small Business Economics, 24(3), 311-321.

Wennekers, A. R. M., \& Thurik, A. R. (1999). Linking entrepreneurship and economic growth. Small Business Economics, 13(1), 27-55.
Wernerfelt, R. (1984). A resource-based view of the firm. Strategic Management Journal, 5(2), 171-180.

Wright, R. W., \& Ricks, D. A. (1994). Trends in international business research: Twenty-five years later. Journal of International Business Studies, 25(4), 687-701.

Yeoh, P.-L. (2004). International learning: Antecedents and performance implications among newly internationalizing companies in an exporting context. International Marketing Review, 21(4-5), 511-535.

Young, S. (1987). Business strategy and the internationalization of business: Recent approaches. Managerial and Decision Economics, 8(1), 31-40.

Young, S., Hood, N., \& Dunlop, S. (1988). Global strategies, multinational subsidiary roles and economic impact in Scotland. Regional Studies, 22(6), 487-497.

Zahra, S. A. (2005). A theory of international new ventures: A decade of research. Journal of International Business Studies, 36(1), 20-28.

Zahra, S. A., Ireland, R., \& Hitt, M. A. (2000). International expansion by new venture firms: international diversity, mode of market entry, technological learning, and performance'. Academy of Management Journal, 43(5), 925950.

Zahra, S. A., Neubaum, D. O., \& Huse, M. (1997). The effect of the environment on export performance among telecommunications new ventures. Entrepreneurship Theory and Practice, 22(1), 25-46. 